\title{
Research on the Relationship Between Digital Music Copyright Infringement Theory and Interest Balance Theory*
}

\author{
Huan $\mathrm{He}$ \\ Institute of Political Science and Law \\ Baicheng Normal University \\ Baicheng, China 137000
}

\begin{abstract}
This paper starts with the basic theory of digital music copyright infringement, analyzes the definition of digital music copyright infringement, the responsibility of infringement and other specific legal issues. Meanwhile, the paper weighs the interests of the three parties, including rights holders, network service providers and network users to seek scientific digital music copyright protection mechanisms through the balance of interest theory.
\end{abstract}

Keywords—digital music; copyright; infringement; balance of interests

\section{INTRODUCTION}

With the development of digital technology, the violation of digital music copyright is becoming more and more common. In the process of perfecting the digital music copyright system, the balance between personal interests and public interests should be emphasized. Specifically, it is suggested that promote the innovation and development of the network industry while strengthening the protection of digital music copyrights.

The interests of digital music copyright mainly include rights holders, network service providers and network users. The network service provider is a new copyright subject not found in the traditional copyright system. It is the backbone of information network communication, the medium connecting digital music rights holders and network users, which plays the role of "communicator" and bearing the spread of digital music and is at the core of the overall digital music copyright system. When designing legal responsibilities for digital music copyright, various factors such as the protection of the interests of the right holders and the development of the network industry should be taken into account. In this case, it is necessary and reasonable to require the network service provider to assume legal responsibility properly. Therefore, how to weigh the interests of all parties in digital music copyright is the key to solving the problem of digital music copyright infringement.

*Project: Research on Legal Protection of Digital Music Copyrigh Under the Network Environment (Jilin Provincial Education Department "13th Five-Year" Social Science Project) Project number: JJKH20190624SK

\section{DEFINITION OF COPYRIGHT INFRINGEMENT OF DigitAl MUSIC}

\section{A. Definition of Copyright Infringement of Digital Music Copyright}

According to the provisions of Article 47 of the Copyright Law, combined with the connotation and characteristics of digital music works, the author defines the concept of "digital music copyright infringement" as follows: the act of exercising the rights enjoyed by the exclusive digital music copyright holders without permission of the copyright owner and in violation of the conditions stipulated by law. If the doer has obtained the permission of the right holder before the act, or there is a statutory legal use case, the act is not a digital music copyright infringement then

\section{THE THEORETICAL ANALYSIS OF THE RESPONSIBILITY OF DIGITAL MUSIC COPYRIGHT INFRINGEMENT}

The rapid development of digital music has also spawned a large number of copyright infringements of digital music. In order to fully protect the copyright of right holders, the law sanctions these unscrupulous people in a responsible manner and requires them to bear corresponding tort liability. The so-called "digital music copyright infringement liability", that is, the legal consequences of the infringement of digital music copyright in the implementation of digital music copyright infringement, the sum of various civil liability methods that should be undertaken according to law. This paper makes an in-depth study of digital music copyright tort liability from the three perspectives of tort liability subject, tort liability bearing mode and tort liability classification.

\section{A. The Subject of Copyright Infringement of Digital Music Copyright}

The main body of digital music copyright infringement mainly includes network service providers and network users.

1) Network service provider:

The invention and development of digital technology has created a new body of music copyright infringement 
liability-Internet Service Provider (ISP). Network service providers are the backbone of network communication and an important information communication medium for network space, ensuring the normal operation of the Internet and the rapid circulation of network information. From the user's point of view, the network world is a huge virtual space. The network is full of huge amounts of information. Without the help of network service providers, it is very difficult for users to obtain instant access to information. For example, a network service provider to Internet is similar to a search tool for a library. The more libraries there are, the more books are available, and the more readers need to use search tools to find target books. Otherwise, manual search is tantamount to "look for a needle in the ocean". Even if it takes a lot of time and effort, it is difficult to find the target books smoothly. It can be seen that after entering the "Internet +" era, people are becoming more and more dependent on network service providers, and the importance of network service providers is becoming more and more prominent. The continuous development of network service providers has also spawned a large number of billionaires.

In the field of digital music, web service providers can directly distribute music or provide a platform for music communication. This subject is not found in the traditional music copyright legal system and is unique to the digital music copyright system. The network service provider maybe either the publisher of digital music or the disseminator of digital music, and the infringement liability of the different network service providers is not the same. In the broad sense, network service providers mainly include network access service providers and network content service providers:

a) Network access service provider: The Internet Access Provider (IAP) is the most indispensable and core subject in the entire network world. It is the basis for the normal operation of the Internet and plays the role of "intermediary". Its business includes establishing network relay stations, renting channels and telephone lines, and establishing connection platforms between network terminal consumers and network content service providers. IAP plays an important pivotal role in the process of network transmission. In the field of digital music copyright, usually, IAP is neutral, which won't become the subject of infringement and doesn't have to bear tort liability, but because of its huge financial resources and high attention, it is often one of the defendants in the lawsuit of digital music works infringement, and becomes the co-defendant with the network content service provider.

b) Web content service provider: The Internet is flooded with vast amounts of information that is constantly being updated at an extremely fast rate. Every moment, people can receive the latest information through the network, learn about the latest developments in the society and master the latest state of the world. The main body that provides this information is the Internet Content Provider ("ICP"), which is called "the source of information" and "information provider". They have the right to choose which information to publish to the public or what information is hidden and disappears within the line of sight of the public. Although the Internet has the characteristics of virtuality and onlineness, the network content service provider can't do whatever it wants. Its implementation activities need to be managed and bound by law. In the field of digital music copyright, if the act of using and distributing digital music copyright by the network content service provider is not approved by the relevant rights holder and doesn't satisfy the liability exemption condition, the act will be classified as an infringement, resulting in the infringement of digital music works.

\section{2) Network users:}

The so-called "network users", also known as "final users", commonly known as "netizens", are passive consumers of music products. The explosive development of the Internet is inseparable from the large number of Internet users. According to the 2016 Internet Trend Report released on June 2, 2016, the number of Internet users worldwide has exceeded 3 billion. In addition, according to the Statistical Report on the Development of China's Internet Network released on August 4, 2017, up to June 2017, the total number of Chinese Internet users has exceeded 750 million, and the Internet penetration rate is about 54.3\%. Through the Internet, netizens can browse, upload and download various information. They can also speak freely to fully express their ideas about a certain thing. In the field of digital music copyright, individual users belong to the most common and largest number of infringement subjects. The earliest digital music copyright dispute with individual users as defendants was in April, 2003, "Four Students Were Prosecuted for Using P2P Music Sharing Software by Recording Industry Association of America". After the incident, until 2007, a large-scale digital music copyright protection activity involving Internet users was launched in the United States. In just five years, the US record industry filed more than 30,000 lawsuits in court, which triggered great controversy in all works of the society. However, not all online users download or copy digital music works constitute infringement. The situation needs to be analyzed case by case based on the use of music works.

\section{B. Digital Music Copyright Infringement Liability}

Digital music copyrights include personal rights and property rights. According to the different infringement objects, the responsibility is not the same. Article 48 of the Copyright Law lists four ways of bearing civil liability, namely, stopping the infringement, eliminating the influence, apologizing and compensating for the loss. The four types of copyright-issued civil liability commitments also apply to digital music copyright infringement disputes. Among them, the compensation loss belongs to the property-type civil liability, and the cessation of infringement, the elimination of the influence and the apology are non-property civil liabilities. Although Article 48 of the Copyright Law doesn't explicitly state it, the above four methods can be applied separately or in combination with the provisions of Article 179 of the General Principles of Civil Law. Since digital music copyrights involve a wide range of proprietary rights, 
in judicial practice, the plaintiff usually claims multiple claims that require the defendant to assume civil liability in multiple ways, and the court often supports the plaintiff's claim in the process of making a judgment in favor of the plaintiff.

\section{Classification of Digital Music Copyright Infringement Liability}

Digital music copyright infringement liability can be classified differently depending on the classification criteria. For example, according to whether the actor directly infringes the copyright exclusive right, the digital music copyright infringement liability can be divided into direct liability and indirect liability; according to the number of the subject of the infringement, the tort liability can be divided into separate tort liability and joint tort liability.

\section{1) Direct responsibility}

China's Copyright Law as well as other laws and regulations don't use the words "direct infringement" and "indirect infringement" in the law. In this regard, some scholars argue that the concept of direct infringement and indirect infringement doesn't belong to the concept within the legal system of China. This type of intellectual property infringement classification is not recognized. However, in the theory of Copyright Law, there has always been a division of "direct infringement" and "indirect infringement". Moreover, this kind of division has been widely used in judicial practice.

If another person directly exercises one or more exclusive rights granted by Copyright Law to the right holder without permission, it constitutes direct infringement. For example, without the permission of the right holder, the behavior to upload the digital music works to the website for other users to listen to and download will constitute the right to directly infringe the digital music information network communication rights; if the digital music works are obtained by the method of damaging the protection measures set by the obligee, it constitutes a direct infringement of digital music reproduction rights. Direct infringement directly involves the work, which is extremely destructive and lasts for a long time. The consequences of the damage are the most serious, and once the direct infringement occurs, it will often bring irreparable losses to the right holder. For example, after a network user pays to download a song, the song is uploaded to the BBS forum for other users to download, thereby earning a point reward. Even if BBS finds the infringement act and immediately closes the song download channel by deleting the post, sealing the number and other ways, the users who have downloaded the song before the song is deleted may become the new direct infringer and use the Internet to spread the song in the same way. In this case, the communication behavior is difficult to be effectively controlled, and the song is very likely to spread through the Internet in a very short period of time, causing the right holder to lose a lot of economic benefits.

In summary, the consequences of direct infringement are very serious. Therefore, for direct infringement, regardless of the subjective fault of the perpetrator, as long as the doer has committed the act of directly infringing the exclusive right of digital music copyright, he or she should bear the tort liability. The subjects responsible for direct responsibility include both network users and network service providers. However, in most cases of digital music copyright infringement disputes, network service providers are not directly responsible, but indirectly responsible.

2) Indirect liability

"Indirect liability" is a concept that corresponds to "direct responsibility". In judicial practice, the infringement of digital music copyright is usually not independently completed by the direct infringer. In order to achieve the infringement purpose, the direct infringer inevitably needs the help, participation and support of the third party. The act of "indirect infringement" doesn't constitute direct infringement, but it provides conditions for direct infringement or extends or expands the consequences of direct infringement. There is a certain causal relationship between the indirect infringer and the damage of the right holder, or it is classified into the category of tort by law because of public policy factors. In the field of digital music copyright, the subject of indirect responsibility is the network service provider, and the infringing object is mainly the information network communication right of digital music. The composition of indirect responsibility is based on the fault of the doer. The introduction of indirect responsibility can effectively expand the scope of digital music copyright protection and strengthen the sense of responsibility of network service providers.

In the field of music copyright, the typical case involving alternative tort liability is the "Shapiro case" in 1963, in which the accused Jalen sold pirated records in the counter provided by the defendant Green. The court of first instance ruled that Green didn't have to bear joint tort liability, and the court of second instance thought that although Green was not directly involved in the infringement, it has management and supervision obligations for Jalen who implemented direct infringement, and drew a portion of the income from Jalen's sales record as a commission. In this case, on one hand, Green had the ability to control Jalen. On the other hand, Green obtained profits from the infringing activities, so Green should bear the corresponding legal responsibility, that is, substitute the tort liability.

\section{USING THE BALANCE OF INTERESTS MECHANISM TO WEIGH THE MAIN INTERESTS INVOLVED IN DIGITAL MUSIC COPYRIGHT}

The balance of interests has always been the core topic in the field of copyright, and it is also the key to solving the problem of copyright infringement of digital music. "In the commodity economy society, everything that people struggle with is related to their interests." Benefits drive people to do or not to do something. The emergence and development of digital technology has had a tremendous impact on the copyright system. All parties involved in the system have carried out a series of activities with the goal of maximizing their own interests. In the process of protecting the copyright of music works, it is necessary to comprehensively consider 
the interests of the three parties of rights holders, network service providers and network users to balance the interests of each subject. With the arrival of the "Internet + " era, digital music has become more and more popular in the music industry. Digital music transmission mode is greatly different from traditional music transmission mode. Besides, digital music copyright involves more subjects and has more complex contents. Therefore, the interest balance in digital music copyright infringement has more particularity and complexity. Only by making the network service provider bear the corresponding responsibility and avoiding the excessive responsibility, can the individual interests and public interests in the digital music copyright system be effectively balanced.

The explosive development of digital communication technology has led to a significant reduction in the cost and difficulty of directly infringing digital music copyrights. Moreover, based on the characteristics of virtuality and concealment of the network, the identity of network users who commit direct infringement is often difficult to identify, and the number is large and the compensation capacity is poor. The indirect tort liability system for network service providers can effectively balance the interests between rights holders and network service providers: on one hand, instead of prosecuting a large number of unknown direct infringers by prosecuting network service providers, maximize the cost of litigation, reduce the difficulty of litigation, and make up for the economic losses of right holders; on the other hand, it can urge network service providers to fulfill their duty of care, so as to raise the registration threshold and develop technical means to stop the direct infringement of digital music copyright to a certain extent. From the perspective of the implementation effect of the copyright indirect infringement liability system, requiring the network service provider to bear the indirect responsibility for the indirect infringement doesn't hinder the development of the network industry, and on the contrary, this kind of behavior can more fully protect the proprietary rights of the right holder to digital music. However, if the tort liability of network service providers is excessively criticized, it will certainly affect the efficiency of network communication and the overall development of network service industry. In countries with developed Internet industry, there is also a development process from strict to loose in solving the problem of digital music copyright infringement liability. Therefore, in terms of the identification of digital music copyright infringement liability and how the responsibility should be undertook, China should learn from the essence of relevant legislation outside the region, adopt a strict attitude to improve the indirect tort liability standard and the form of liability standard.

\section{CONCLUSION}

In summary, digital music copyright infringement must fully protect the rights and interests of rights holders through digital means. However, how to weigh the interests of the three parties of rights holders, network service providers and network users is the key to solving the problem of digital music copyright infringement. Only by making the network service provider bear the corresponding responsibility and avoiding the excessive responsibility, can the individual interests and public interests in the digital music copyright system be effectively balanced. Controlling the behavior of network service providers can reduce the infringement of digital music works from the root cause, thereby more fully protecting digital music copyrights. However, this kind of control also needs to be limited to prevent the development of the network industry from being interfered by excessive interference.

\section{REFERENCES}

[1] Kong Xiangjun. The Legal Concept and Judgment Method of Network Copyright Protection [M]. China Legal Publishing House, 2015. (in Chinese)

[2] Wang Liming. Research on Tort Liability [M]. Renmin University of China Press, 2016. (in Chinese)

[3] Liang Qinghua. Intellectual Property Protection under the Network Environment [M]. China Legal Publishing House, 2004. (in Chinese)

[4] Guo Nana. The Impact of Tort Liability of Internet Service Providers on Freedom of Speech-Taking Article 36 of the Tort Liability Law as the Entry Point [D]. Master's thesis of Shandong University, 2017(3). (in Chinese)

[5] Li Chongting. On the Tort Liability of Network Providers [J]. Inner Mongolia University of Science and Technology Legal System Expo, 2016 (6). (in Chinese) 